
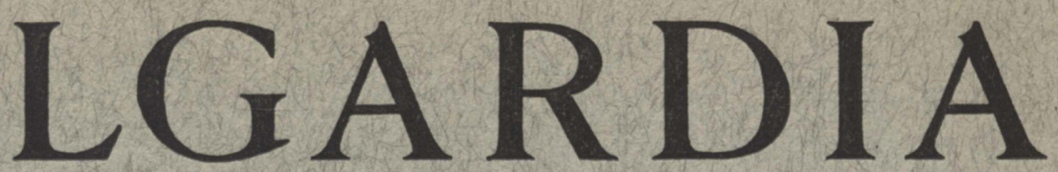

A Journal of Agricultural Science Publisbed by the California Agricultural Experiment Station

CONTENTS

NEWLY DISCOVERED LEAFHOPPER

VECTORS OF CALIFORNIA

ASTER-YELLOWS VIRUS

HENRY H. P. SEVERIN

CHARACTERS, DISTRIBUTION, AND FOOD PLANTS OF NEWLY DISCOVERED VECTORS OF CALIFORNIA ASTER-YELLOWS VIRUS DWIGHT M. DELONG AND HENRY H. P. SEVERIN

LONGEVITY OF NONINFECTIVE AND INFECTIVE LEAFHOPPERS ON A PLANT NONSUSCEPTIBLE TO A VIRUS HENRY H. P. SEVERIN 


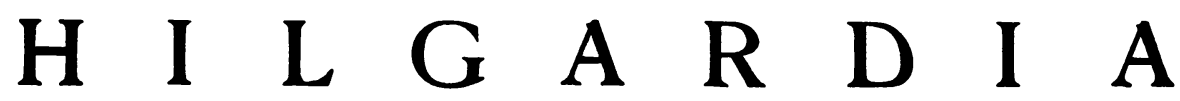

A Journal of Agricultural Science Published by

the California Agricultural Experiment Station

\section{NEWLY DISCOVERED LEAFHOPPER VECTORS OF CALIFORNIA ASTER-YELLOWS VIRUS ${ }^{1}$}

\author{
HENRY H. P. SEVERIN ${ }^{2}$
}

\section{INTRODUCTION}

SoME YEARS AGo three species of leafhoppers and a biological race of one of them were reported to transmit the California aster-yellows virus (Severin, $1929,1934,1940){ }^{3}$ Recently eight additional leafhopper species were added to the list of vectors of this virus (Severin, 1945, 1946, 1947).

The present paper deals with five newly discovered leafhopper vectors of this virus. In a companion paper DeLong and Severin (1947) discuss the characters, distribution, and food plants of these species.

An investigation was undertaken on the efficiency of the vectors in transmitting the virus by single males and females to healthy celery and asters. Multiple-lot tests were performed with several species. With three species, studies were made of the retention of the virus in single adults. Natural infectivity tests were made with two species. With some species, attempts were made to transmit the viruses of curly top to sugar beets and Pierce's disease of grapevines to grapevine cuttings or seedlings and the identical virus from alfalfa dwarf to healthy alfalfa.

The technique and equipment have been described in previous papers (Severin, 1930, 1931, 1945, 1946, 1947).

\section{CLOANTHANUS IRRORATUS (VAN DUZEE)}

$$
\text { (Plate 1, } A, B \text { ) }
$$

Transmission of Virus to Celery and Asters. Fifty recently molted males and 50 females of Cloanthanus irroratus (Van Duzee), which had completed the nymphal stage on diseased celery, were kept singly on 100 celery plants until symptoms of the disease developed or during adult life if no symptoms ap-

\footnotetext{
${ }^{1}$ Received for publication August 13, 1945.

2 Entomologist in the Experiment Station.

${ }^{3}$ See "Literature Cited" for citations, referred to in the text by author and date.
} 
peared. Table 1 shows that only 1 of 50 males caused an infection, and none of the 50 females.

Lots of 5, 10, 20, and 40 adults were transferred from infected to healthy celery plants and when symptoms of the disease developed, each lot was changed to a healthy aster. If no symptoms appeared on celery at the end of approximately 2 months, then the surviving adults in each lot were transferred and kept on a healthy aster until the last leafhopper died. There was a progressive increase in the percentages of infections of celery with lots of $5,10,20$,

TABLE 1

Transmission of Virus to Celery and Asters, by Varying Numbers of Adult Cloanthanus irroratus

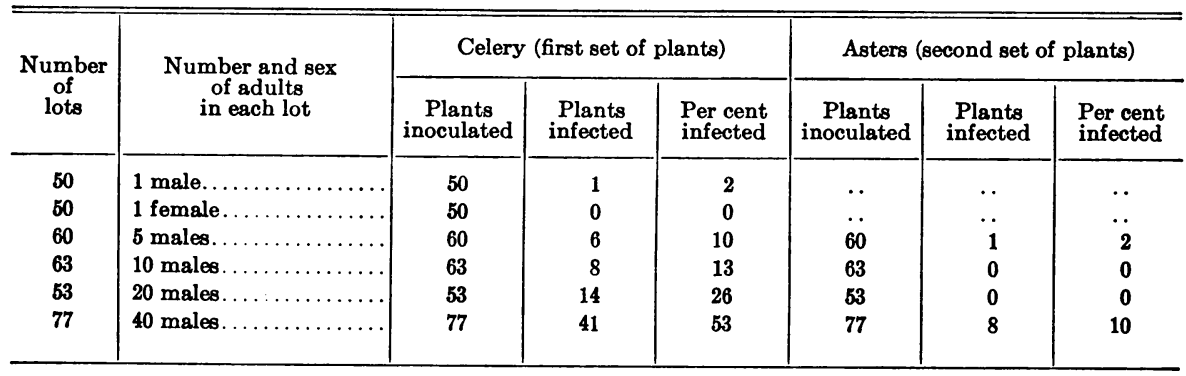

TABLE 2

Transmission of Virus to Asters by Varying Numbers of Adult Cloanthanus irroratus

\begin{tabular}{|c|c|c|c|c|}
\hline $\begin{array}{l}\text { Number } \\
\text { of lots }\end{array}$ & $\begin{array}{l}\text { Number and sex of adults } \\
\text { in each lot }\end{array}$ & $\begin{array}{c}\text { Asters } \\
\text { inoculated }\end{array}$ & $\begin{array}{c}\text { Asters } \\
\text { infected }\end{array}$ & $\begin{array}{l}\text { Per cent } \\
\text { infected }\end{array}$ \\
\hline 50 & 1 male.. & 50 & 1 & 2 \\
\hline 50 & 1 female..$\ldots \ldots \ldots \ldots \ldots$ & 50 & 0 & 0 \\
\hline 10 & 20 males $\ldots \ldots \ldots \ldots \ldots \ldots$ & 10 & $\mathbf{0}$ & $\mathbf{0}$ \\
\hline 43 & 40 males $\ldots \ldots \ldots \ldots \ldots \ldots \ldots$ & 43 & 8 & 19 \\
\hline
\end{tabular}

and 40 leafhoppers, as shown in table 1, indicating that the number of leafhoppers plays an important role in the transmission of the virus. There was, however, no progressive increase in the percentages of infection of asters.

Since a mortality of the leafhoppers occurred on healthy celery in the previous experiment, another test was made with lots of varying numbers of males or females transferred from diseased celery to healthy asters. Table 2 shows that only 1 aster was infected by 50 males and 50 females tested singly on asters. Lots of 20 males caused no infections. Lots of 40 males infected 19 per cent of the asters as compared with 10 per cent in the previous experiment (table 1).

Retention of Virus by Single Adults. The retention of the virus was determined with the only leafhopper-a male - that produced an infection of celery in the single-insect tests (table 1). The first celery plant showed symp- 
toms at the end of 19 days. The leafhopper was then transferred daily to successive healthy celery plants during adult life; it transmitted the virus to another celery plant 15 days after the first infection. The incubation period of the disease of the first infection cannot be included in the retention of the virus, since the leafhopper had an opportunity to acquire additional virus after the first celery plant became infected. The longevity of the male was 76 days.

Attempts to Transmit Viruses of Curly Top and Pierce's Disease of Grapevine. Seventeen lots of 20 male Cloanthanus irroratus, after feeding on curlytop beets from 1 to 2 weeks, failed to transmit the virus to 17 healthy beets. Fifteen lots of 40 noninfective $C$. irroratus failed to transmit the virus of Pierce's disease of grapevines to healthy grape seedlings and to plants of California Common or Chilean alfalfa, Medicago sativa; or from alfalfa dwarf to healthy grape and alfalfa plants.

\section{CLOANTHANUS DUBIUS (VAN DUZEE)}

(Plate 1, $C, D$ )

Transmission of Virus to Celery. The efficiency of Cloanthanus dubius (Van Duzee) in transmitting the virus was determined with 50 males and 50 females, each kept singly on a healthy celery plant. If symptoms of the disease developed, each surviving leafhopper was used in determining the retention of the virus, and if no symptoms appeared, the adults were kept on each healthy celery plant during adult life. Eleven males and 2 females, or 13 per cent, caused infections.

Tests were made on the transmission of the virus by lots of 20 and 40 males, each transferred weekly to 6 successive healthy celery plants, and by lots of the same number of males transferred at intervals of 2 weeks. As table 3 shows, the total percentage of infection in weekly inoculations was 23 both for lots of 20 and for lots of 40 adults, as compared with 27 and 47 per cent with lots of 20 and 40 males at 2 -week intervals.

TABLE 3

Transmission of Virus to Successive Celery Plants by Varying Numbers of MALE Cloanthanus dubius

\begin{tabular}{|c|c|c|c|c|c|c|c|c|c|}
\hline \multirow{2}{*}{$\begin{array}{l}\text { Period of inoculations } \\
\text { and number } \\
\text { of adults in each lot }\end{array}$} & \multicolumn{6}{|c|}{ Plants infected in each set* } & \multicolumn{3}{|c|}{ Total } \\
\hline & $\begin{array}{c}\text { First } \\
\text { set }\end{array}$ & $\begin{array}{c}\text { Second } \\
\text { set }\end{array}$ & $\begin{array}{c}\text { Third } \\
\text { set }\end{array}$ & $\begin{array}{c}\text { Fourth } \\
\text { set }\end{array}$ & $\begin{array}{c}\text { Fifth } \\
\text { set }\end{array}$ & $\begin{array}{l}\text { Sixth } \\
\text { set }\end{array}$ & $\begin{array}{l}\text { Plants } \\
\text { inocu- } \\
\text { lated }\end{array}$ & $\underset{\text { infected }}{\text { Plants }}$ & $\begin{array}{l}\text { Per cent } \\
\text { infected }\end{array}$ \\
\hline \multicolumn{10}{|l|}{ Weekly inoculations: } \\
\hline $20 \ldots \ldots \ldots \ldots \ldots \ldots$ & 1 & 1 & 1 & 2 & 2 & 0 & 30 & 7 & 23 \\
\hline $40 \ldots \ldots \ldots \ldots \ldots \ldots$ & 1 & 1 & 1 & 1 & 1 & 2 & 30 & 7 & 23 \\
\hline \multicolumn{10}{|l|}{ Inoculations every 2 weeks: } \\
\hline $20 \ldots \ldots \ldots \ldots \ldots \ldots \ldots \ldots$ & 1 & 3 & 2 & 0 & 0 & 1 & 30 & 8 & 27 \\
\hline $40 \ldots \ldots \ldots \ldots \ldots \ldots \ldots \ldots \ldots$ & 4 & 4 & 4 & 1 & 1 & 0 & 30 & 14 & 47 \\
\hline
\end{tabular}

- Five plants inoculated in each set. 
Attempts to Transmit Virus to Asters. Fifty males and 50 females, each kept singly on healthy asters, failed to cause infections. The males lived from 1 to 12 days, an average of 3.3 days, and the females from 1 to 7 days, an average of 2.4 days, on healthy asters.

One lot of 40 males was caged on a healthy aster and after 2 weeks the surviving adults, 7 in number, were transferred to a second aster, but no infection occurred.

Retention of Virus by Single Adults. The retention of the virus was ascertained with adults previously used in determining the efficiency of the vector in transmitting virus by single insects. After the first infection the leafhoppers were transferred daily to successive healthy celery plants during adult life.

TABLE 4

Retention of Virus by Single Adults of Cloanthanus dubius with Celery as the Host Plant

\begin{tabular}{|c|c|c|c|c|c|c|}
\hline Insect no. and sex & $\begin{array}{l}\text { Days on } \\
\text { first plant } \\
\text { before } \\
\text { symptoms } \\
\text { developed }\end{array}$ & $\begin{array}{c}\text { Plants } \\
\text { inoculated } \\
\text { after } \\
\text { initial } \\
\text { infection }\end{array}$ & $\begin{array}{l}\text { Plants } \\
\text { infected } \\
\text { after } \\
\text { initial } \\
\text { infection }\end{array}$ & $\begin{array}{l}\text { Per cent } \\
\text { infected } \\
\text { after } \\
\text { initial } \\
\text { infection }\end{array}$ & $\begin{array}{c}\text { Days after } \\
\text { initial } \\
\text { infection } \\
\text { on which } \\
\text { successive } \\
\text { infections } \\
\text { occurred }\end{array}$ & $\begin{array}{l}\text { Longevity } \\
\text { of adults, } \\
\text { days }\end{array}$ \\
\hline 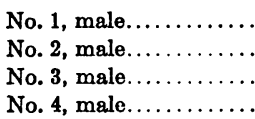 & $\begin{array}{l}36 \\
22 \\
28 \\
46\end{array}$ & $\begin{array}{r}28 \\
55 \\
135 \\
5\end{array}$ & $\begin{array}{l}4 \\
3 \\
2 \\
1\end{array}$ & $\begin{array}{r}14 \\
5 \\
2 \\
20\end{array}$ & $\begin{array}{l}17,22,27,28 \\
23,24,29 \\
1,2 \\
2\end{array}$ & $\begin{array}{r}64 \\
77 \\
163 \\
51\end{array}$ \\
\hline
\end{tabular}

Table 4 shows that the virus was retained from 1 to 29 days. As with Cloanthanus irroratus, the incubation period of the disease of the initial infection is not included in the retention of the virus.

Attempt to Transmit Curly-Top Virus. Extensive tests were made to determine whether this species of leafhopper was a vector of the curly-top virus. All attempts to transmit the curly-top virus to healthy sugar-beet seedlings were negative.

\section{EUSCELIS MACULIPENIS DELONG AND DAVIDSON}

$$
\text { (Plate 1, E, F) }
$$

Transmission of Virus to Celery. The efficiency of Euscelis maculipenis DeLong and Davidson in transmitting the virus was determined with recently molted males and females, reared during the nymphal stages on diseased celery, and then each adult was transferred singly to a healthy celery or aster plant. Single males and females infected 78 and 76 per cent of the celery plants, respectively, but none of the 100 asters inoculated, as shown in table 5 .

When symptoms developed on celery, some of the insects were transferred singly to a second celery plant. These leafhoppers had an opportunity to acquire the virus again from the first infected celery. Eighteen of 21 males 
infected 18 of 21 plants, or 86 per cent. Seventeen females each infected a celery plant, but when transferred singly to healthy asters failed to infect any.

The longevity of the males on healthy asters ranged from 1 to 35 days, with an average of 3 days; females 1 to 24 days, with an average of 3 days.

TABLE 5

Transmission of Virus by Three Vectors Tested Singly to Two Host Plants

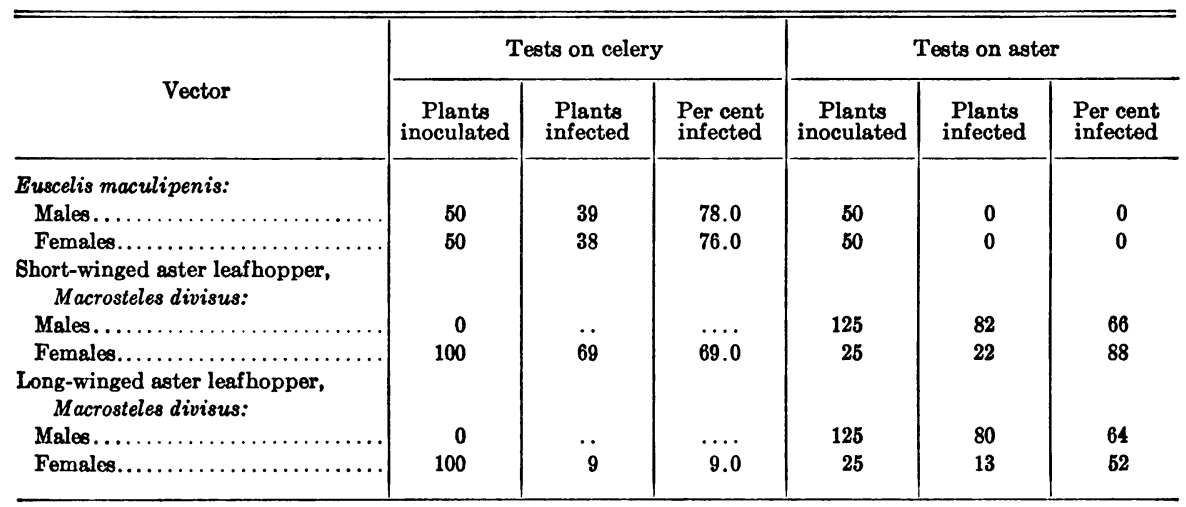

TABLE 6

Retention of Virus with Single Adult Euscelis maculipenis with Celery as the Host Plant

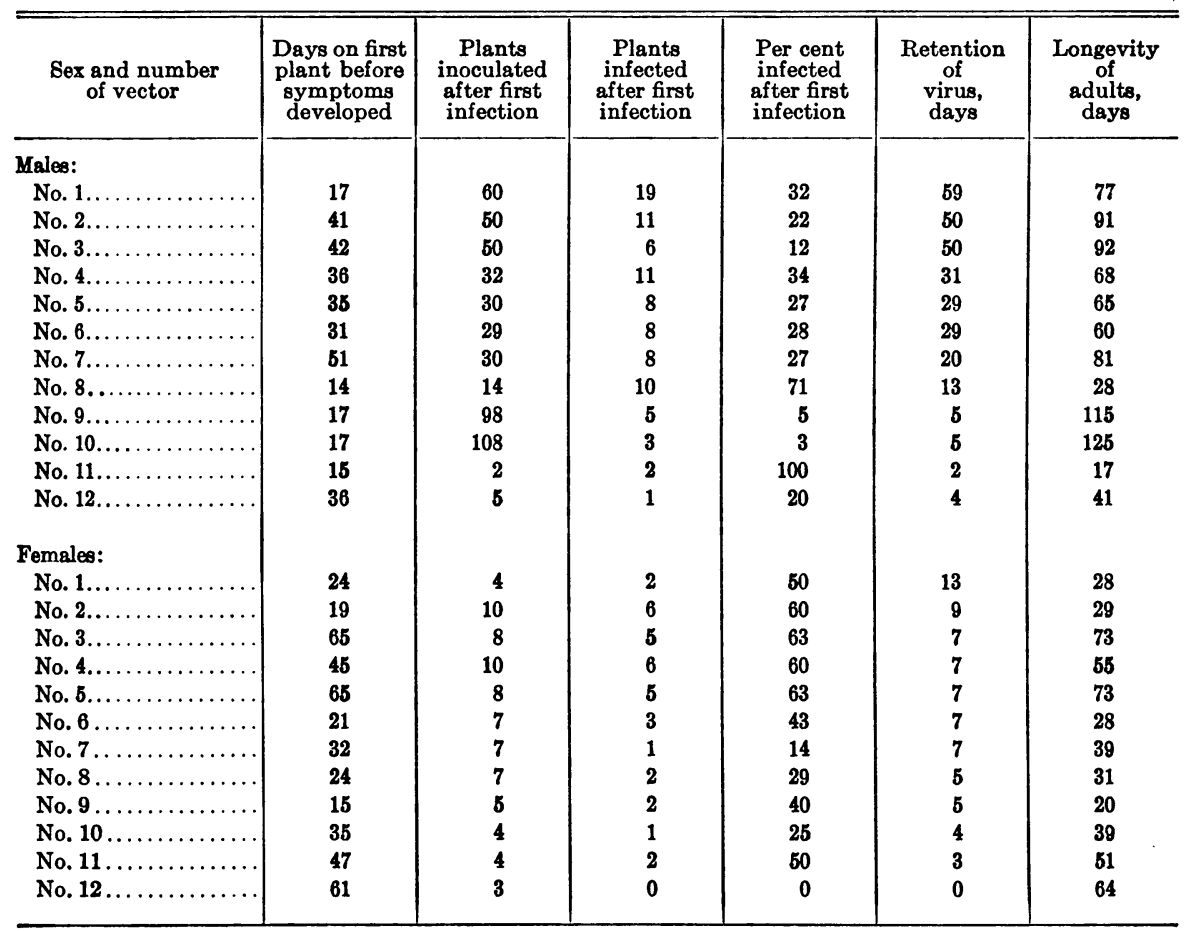


Retention of Virus by Single Adults. The retention of the virus was determined with single males and females that had transmitted the virus in tests of vector efficiency. Each insect was provided with a healthy celery plant daily during adult life. The results appear in table 6 . As this table shows, the males retained the virus from 2 to 59 days, and the females from 3 to 13 days. The period before symptoms developed on the first celery plant is not included in virus retention, since the adult was able to recover the virus again. One male produced only 1 infection.

Natural Infectivity. Plantain, or ribgrass, Plantago major, growing in an alfalfa field near Milpitas and along roadsides, was found commonly infected with aster yellows. Nymphs and adults were often collected in this alfalfa field in the spring, but during the autumn the adults were rarely taken. Two adults captured in this alfalfa field on August 23, 1945, did not transmit the virus to celery.

Sweepings were made on common dandelion, Taraxacum vulgare, growing in South San Francisco, on August 20, 1945, and 3 nymphs and 30 adults were taken in half an hour. Some of the dandelion plants were infected with aster yellows, but the virus was not transmitted to celery.

Attempts to Transmit Viruses of Curly Top and Pierce's Disease of Grapevines. Ten lots of 5 adults, after feeding on curly-top beets for a period of 4 days, failed to transmit the virus to 10 healthy sugar-beet seedlings. The longevity of the adults ranged from 18 to 69 days.

No success was achieved in attempts to transmit the virus of Pierce's disease of grapevines from diseased vines to healthy wild-grape seedlings or from alfalfa plants infected with dwarf to healthy grape seedlings with this leafhopper.

\section{MACROSTELES DIVISUS (UHLER)}

Further Tests of Efficiency of Virus Transmission. In working with a large number of newly discovered leafhopper vectors of the California asteryellows virus, it soon became evident that the ability to transmit the virus varied with different species. For the purpose of comparison, efficiency tests were conducted with the short-winged and long-winged aster leafhoppers, Macrosteles divisus (Uhler), which are known to be efficient vectors of the virus. The long-winged aster leafhopper is a biological race (Severin, 1940).

Short-winged and long-winged aster leafhoppers were reared on asters and on celery infected with the virus. High populations of infective short-winged aster leafhoppers were reared on diseased celery and low numbers of noninfective adults on healthy celery. Low populations of infective long-winged adults were obtained on diseased celery, but the nymphs died after the first molt on healthy celery.

Transmission of Virus to Celery and Asters. The efficiency of both vectors in transmitting the virus was determined with single leafhoppers. Twenty-five to 125 males and females that had completed the nymphal stages on diseased 
celery or asters were kept singly on healthy celery or asters until symptoms developed, or during adult life if no symptoms appeared. The results obtained are given in table 5 .

As shown in table 5, short-winged aster leafhoppers tested singly infected 69 per cent of the celery plants, and 66 to 88 per cent of the asters, or an average of 69 per cent. Long-winged aster leafhoppers infected 9 per cent of the celery and 52 to 64 per cent of the asters, or an average of 62 per cent.

The longevities of 4 long-winged males which caused infections were 1,10 , 31 , and 42 days, or an average of 26 days, and of 5 females $4,6,22,28$, and 42 days, or an average of 20 days. The longevity of 46 males which failed to cause infection ranged from 1 to 40 days, with an average of 6 days, and of 45 females from 2 to 38 days, with an average of 14 days.

Natural Infectivity. A comparison was also made of the natural infectivity of short-winged aster leafhoppers with Euscelis maculipenis collected on the same dates in the same habitats. Fifteen short-winged aster leafhoppers captured in an alfalfa field near Milpitas transmitted the virus to asters, but $E$. maculipenis failed to transmit it to celery. Eleven short-winged aster leafhoppers taken on common dandelion growing in South San Francisco transmitted the virus to asters, but 3 nymphs and 30 adults of $E$. maculipenis failed to infect celery.

\section{FIEBERIELLA FLORII (STÅL)}

$$
\text { (Plate 1, } G, H \text { ) }
$$

Adult Fieberiella florii (Stål) collected in the field were kept on infected celery for 10 days or longer to complete the latent period of the virus in the insect. Fifty males and 50 females tested singly on healthy celery plants during adult life, transmitted the virus to 9 plants, or 18 per cent, and 11 plants, or 22 per cent, respectively. Eighteen lots of 5 adults produced 8 infections, or 44 per cent.

\section{CHLOROTETTIX SIMILIS DeLONG}

$$
\text { (Plate } 1, I \text { ) }
$$

Chlorotettix similis DeLong has not been reared on any food plants up to the present time. This is further discussed in a companion paper (DeLong and Severin, 1947).

Adults collected in the field were kept on infected celery plants for 10 days or longer. Eight leafhoppers were then transferred singly and kept on healthy celery plants during adult life. The rest of the leafhoppers were transferred in multiple lots to successive healthy celery plants. One of the 8 adults in singleinsect tests infected 1 plant. One lot of 3 adults transmitted the virus to 1 of 2 plants. One lot of 30 adults produced 1 infection and 13 surviving adults caused another infection. Lots of 16 and 20 adults failed to transmit the virus to 5 celery plants. Of the total of 17 plants inoculated, 4 were infected, or 23 per cent. The longevities of the last adult in 2 lots were 60 and 106 days, respectively, on healthy celery. 
Chlorotettix similis failed to transmit the curly-top virus. One lot of 30 adults was kept on a curly-top beet for 4 days and then transferred to a healthy beet for 2 days. The surviving adults were transferred alternately to curly top and healthy beets during adult life, but no disease resulted.

\section{SUMMARY}

With single-insect tests, the following percentages of transmission of California aster-yellows virus were obtained:

\begin{tabular}{|c|c|c|}
\hline Macrosteles divisus: & To celery & To asters \\
\hline Short-winged. & 69 & 69 \\
\hline Long-winged. . & 9 & 62 \\
\hline Cloanthanus irroratus. . & 1 & 1 \\
\hline Cloanthanus dubius. & 13 & 0 \\
\hline Euscelis maculipenis.. & 77 & $\mathbf{0}$ \\
\hline Fieberiella florii. . & 20 & . \\
\hline Chlorotettix similis. & 12 & . \\
\hline
\end{tabular}

When from 5 to 40 insects per plant were used, percentages of transmission to celery were increased with all species tested (Cloanthanus irroratus, Cloanthanus dubius, long-winged Macrosteles divisus, Fieberiella florii, and Chlorotettix similis), and to aster with Cloanthanus irroratus. Cloanthanus dubius failed to transmit the virus to aster even with multiple lots. Other species were not tested in multiple lots on aster.

The virus was retained for a maximum of 15 days by Cloanthanus irroratus, 29 days by $C$. dubius, and 59 days by Euscelis maculipenis. Virus retention was not studied on other species.

Unsuccessful attempts were made to transmit the virus of Pierce's disease of grapevines to grape seedlings with two species (Cloanthanus irroratus and Euscelis maculipenis) and the virus of curly top to beets with three species (the two just listed and C.dubius). 


\section{LITERATURE CITED}

DeLong, D. M., and H. H. P. Severin.

1947. Characters, distribution, and food plants of newly discovered vectors of California aster-yellows virus. Hilgardia 17(16):527-38

Severin, H. H. P.

1929. Yellows disease of celery, lettuce, and other host plants transmitted by Cicadula sexnotata (Fall.). Hilgardia 3(18): 543-83.

1930. Life-history of beet leafhopper, Eutettix tenellus (Baker) in California. Univ. Calif. Publ. Entom. 5:37-88.

1931. Modes of curly-top transmission by the beet leafhopper, Eutettix tenellus (Baker). Hilgardia 6:253-76.

1934. Transmission of California aster and celery-yellows virus by three species of leafhoppers. Hilgardia 8(10):339-61.

1940. Potato naturally infected with California aster-yellows virus. Phytopathology 30(12):1049-51.

1945. Evidence of nonspecific transmission of California aster-yellows virus by leafhoppers. Hilgardia 17(1):22-60.

1946. Transmission of California aster-yellows virus by the first reported leafhopper vector in Gyponinae. Hilgardia 17(3):141-53.

1947. Acinopterus angulatus, a newly discovered leafhopper vector of California asteryellows virus. Hilgardia 17(3):141-53. 

PLATE 


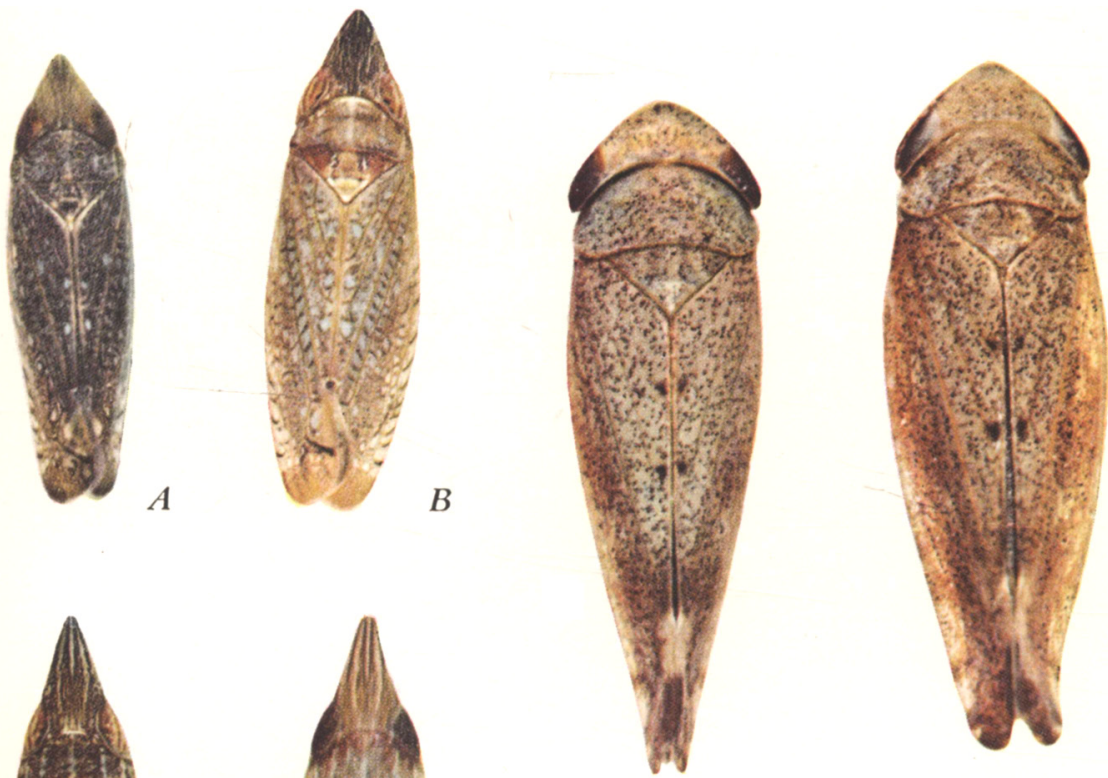

G
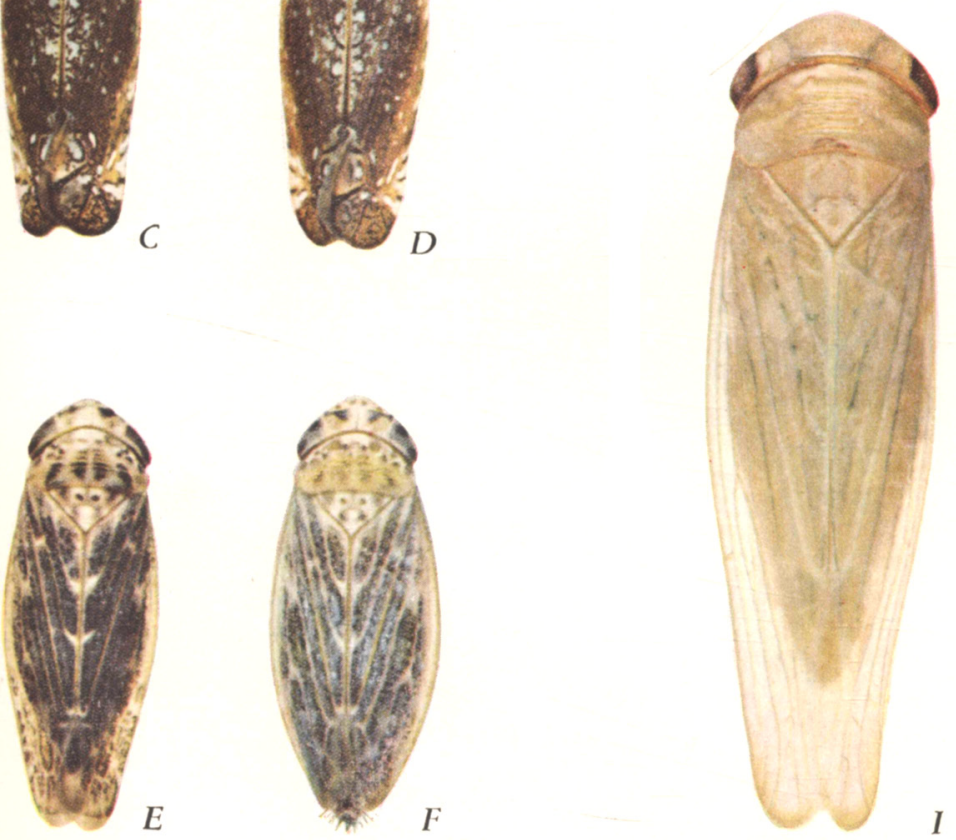

Plate 1.-A, Male, $B$, female Cloanthanus irroratus (Van Duzee); $C$, male, $D$, female Cloanthanus dubius (Van Duzee) ; $E$, male, $F$, female Euscelis maculipenis DeLong and Davidson; $G$, male, $H$, female Fieberiella florii (Stål); I, female Chlorotettix similis DeLong. 

